\title{
THE LEXICOGRAPHIC PROBLEMS OF COMPILING ARGOT DICTIONARIES
}

\author{
Mikhail. A. Grachev \\ Nizhniy Novgorod State Linguistic University named after N.A. Dobrolubov, Nizhniy Novgorod, Russia
}

\begin{abstract}
The article argues for the need to compile a new fundamental argotic dictionary on a scientific basis. Using the comparative and historical method, the paper provides the criticism of the previous lexicons reflecting the language of the criminal world. With respect to the mistakes and inaccuracies made by compilers of the available dictionaries, the author develops the principles of lexicographic representation of the Russian argot, determines the sources of the language material included in the dictionary (folklore, old Russian literature, speech of modern representatives of the criminal subculture), proposes criteria and methods of the qualifying a lexical unit as argot. The article describes the new dictionary structure that reflects complex characteristics of its constituent units (a headword with stress, reference articles, meaning interpretation, context of use, phraseological units, grammatical characteristics, etymology). It also identifies tendencies of the modern Russian argot evolution caused by the influence of changes in the Russian society in general and in the criminal world in particular, as well as the reasons for penetrating argot in the spoken language and media texts. Besides, the paper shows the possibilities of using the new qualitative linguistic dictionary to study the linguistic picture of the world of argot speakers, to form an objective evaluation of this phenomenon and to improve the speech culture of Russian society.
\end{abstract}

Key words: dictionary, argot, evolution, lexicography, jargon, the Russian language.

Citation. Grachev M.A. The Lexicographic Problems of Compiling Argot Dictionaries. Vestnik Volgogradskogo gosudarstvennogo universiteta. Seriya 2, Yazykoznanie [Science Journal of Volgograd State University. Linguistics], 2019, vol. 18, no. 1, pp. 62-73. (in Russian). DOI: https://doi.org/10.15688/jvolsu2.2019.1.5

УДК 811.161 .1 '276.45

Дата поступления статьи: 22.01.2019

ББК 81.411.2-025.7

Дата принятия статьи: 04.03.2019

\section{ЛЕКСИКОГРАФИЧЕСКИЕ ПРОБЛЕМЫ СОСТАВЛЕНИЯ СЛОВАРЕЙ АРГО}

\author{
Михаил Александрович Грачев \\ Нижегородский государственный лингвистический университет им. Н.А. Добролюбова, \\ г. Нижний Новгород, Россия
}

\begin{abstract}
Аннотация. В статье аргументируется необходимость составления нового фундаментального арготического словаря на научной основе. С использованием сравнительно-исторического метода дана критика предшествующих лексиконов языка криминального мира. С учетом ошибок и неточностей, допущенных составителями имеющихся словарей, разработаны принципы лексикографического представления русского арго, определены источники языкового материала, включаемого в словарь (фольклор, древнерусская литература, речь современных носителей криминальной субкультуры), предложены критерии и методика квалификации той или иной лексической единицы как арго. Описана структура нового словаря, отражающая комплексную характеристику входящих в него единиц (заглавное слово с ударением, ссылочные статьи, حолкование, контекст употребления, фразеологизмы, грамматическая характеристика, этимология). Выявле¿ ¿ сийском социуме в целом и в криминальном мире в частности, а также причины проникновения арго в разговорный язык и тексты СМИ. Показаны возможности использования нового качественного лингвисти仓 ческого словаря для изучения языковой картины мира носителей арго, формирования объективной оценки этого феномена, повышения речевой культуры российского общества.
\end{abstract}

Ключевые слова: словарь, арго, эволюция, лексикография, жаргон, русский язык. 
Цитирование. Грачев М. А. Лексикографические проблемы составления словарей арго // Вестник Волгоградского государственного университета. Серия 2, Языкознание. - 2019. - T. 18, № 1. - C. 62-73. - DOI: https://doi.org/10.15688/jvolsu2.2019.1.5

\section{Актуальность создания нового словаря арго}

Необходимость подготовки нового словаря арго обусловлена многими причинами. Охарактеризуем главные из них.

Во-первых, арго - часть русского языка, и она должна быть не только изучена, но и зафиксирована в словарях. В настоящее время появился новый стиль устной речи, характеризующийся объединением нормированных слов с социолектизмами, большую долю среди которых составляют арготизмы. В то же время лексика криминального мира (беспредел, заказать, тусовка, разборка и проч.) активно переходит в литературный языквысшую форму существования любого языка, в том числе русского. Лингвистам необходимо дать научную оценку этому явлению прежде всего потому, что арготизмы - агрессивная лексика, которая негативно влияет на сознание носителей языка, и установить причины ее перехода в художественную литературу, публицистику, просторечие, молодежные жаргоны и т. п.

Во-вторых, детальное изучение арго дает новые сведения для истории русского языка, в частности истории его лексической системы, поскольку в социальных диалектах, в том числе в арго, сохранилось много древнерусских элементов, в связи с тем, что носители арго - это одна из устойчивых социальных групп, законы и порядки которой консервативны, ее субкультура, включая язык, передавалась из поколения в поколение.

В-третьих, многие современные произведения, описывающие мир уголовников, являются своего рода памятником отечественной жаргонологии. Их эстетическое несовершенство и коммуникативная слабость обусловлены тем, что язык таких произведений непонятен не только русскоязычному, но и иностранному читателю. Кроме того, в настоящее время много арготизмов используется в СМИ, тексты статей порой также непрозрачны для читателей. Отчасти преодолеть непо- нимание возможно при обращении к специализированному словарю арго.

В-четвертых, такой словарь может быть полезен в работе криминалистов при установлении различных связей русских деклассированных элементов с зарубежными, при выявлении наиболее устойчивых законов и порядков уголовной среды. Эти знания могут быть использованы в профилактической работе для предупреждения преступлений.

В-пятых, у филологов до сих пор нет словаря-справочника русских социолектных слов, предназначенного для переводчика, и следовательно, возникает проблема адекватного перевода разнообразных текстов (прежде всего художественных). Например, часто возникают трудности при передаче на другой язык фразеологизма вор в законе, ибо то, что он обозначает, является исключительно российским феноменом.

При переводе нужно знать особенности эпохи, социального колорита, проводить хронологическую параллель между обстановкой, в которой функционируют русские и нерусские арготизмы, учитывать их эмоционально-экспрессивную окраску. Именно подбор эквивалентов, соответствующих друг другу по степени экспрессивности, представляется наиболее трудной задачей для переводчиков.

Ярким примером наличия трудностей в подборе русских арготизмов является перевод «Баллад на воровском жаргоне» Франсуа Вийона, выполненный разными переводчиками. Приведем фрагмент из баллады «Хорош, ребята, город Парижуха»: Зapáчam и в мешо́к отправят к псам / Коль не попустит Бог с пенько́й спознаться. / Кана́йте на созна́нку к живодеру, / Как только засунду́чут вас в канде́й. / Зря не темни́те - и без разговору / Задо́к-другой скостя'т вам ейже-ей. / На ки́че с петель не сорвешь дверей, / Туда с собой не притара́нишь слам, / Чтобы, подма́зав ла́пу дубака́м, / C ux помощьью невки́пиш оборва́твся... (Вийон, с. 154). Думается, что в целом качественный перевод все же не передает дух парижского «дна» середины XV в., так как эквивалента- 
ми для слов французского арго явились русские арготизмы XIX-XX вв., что обусловлено, по-видимому, отсутствием не только двуязычного, но и русскоязычного словаря арго, отражающего разные этапы развития этого языкового субстрата. При переводе баллад $Ф$. Вийона не использовались и возможности сносок или словника употребленных арготизмов, а следовательно, читателю придется обращаться к имеющимся русским и французским словарям арго, чтобы определить точное значение слова. Переведем: зара́чuть «арестовать», мешо́к - «тюрьма», пес - «сотрудник правоохранительных органов», пенька́ - «виселица», кана́ть на созна́нку «сознаваться в совершенном преступлении», живодер - «следователь; палач», засунди́чить - «поместить; арестовать», ка(о)нде́ŭ «карцер», задо́ скости́mь - «простить», ки́ча - «тюрьма», притара́нить - «принести», слам - «воровская доля добычи; взятка», подма́зать ли́a $n y$ - «дать взятку», дуба́к - «охранник», невки́nиш - «осторожно; удачно», оборва́ться - «убежать».

В связи с отсутствием лингвистической справочной литературы при передаче иноязычных арготизмов на русский язык переводчик вынужден придумывать новые слова. Так, в переводе романа В. Гюго «Отверженные», выполненном под редакцией А. Виноградова, находим слова плет - «бегство», потьми́uник - «ночной вор» (Гюго, с. 216). Этих слов в русском арго нет, но есть плетова́ть - «бежать из мест лишения свободы», темный «краденый, фальшивый».

Неточный перевод хотя бы нескольких слов влечет за собой и «просчеты» в идейнохудожественном и эстетическом планах.

Важной задачей переводчика является и сохранение эмоционально-экспрессивной окраски переводимых единиц. При составлении двуязычных словарей, и в частности, словарей арго, наряду с семантической адекватностью должно учитываться и функциональное, а точнее, регистровое соответствие единиц. Это необходимо не только в плане верности перевода, но и в целях воспроизведения всего объема социальной экспрессивной и концептуальной информации, заложенной в лексиконе сопоставляемых языков. Например, во француз- ской лексикографической практике долгое время наблюдалась нечеткость при определении функционального статуса лексических единиц арго. Отсутствие единых критериев и излишняя дробность классификаций привели к появлению в словарях большого количества лексикографических помет (подробно об этом см.: [Грачев, Сапожникова, 2004, с. 37]).

Мы охарактеризовали часть широкого спектра причин, обусловливающих необходимость создания нового словаря русского арго, и обозначили некоторые задачи, которые можно решать с помощью такого словаря.

\section{Словари русского арго: критический анализ}

Изданные и рукописные русские арготические словари имеют ряд недостатков:

a) наличие орфографических и пунктуационных ошибок; (см., например, словник М. Никонорова «Сборник жаргонных слов и выражений, употребляемых в устной и письменной форме преступным элементом» (Никоноров) и работу И. Вориводы «Сборник жаргонных слов и выражений, употребляемых в устной и письменной речи преступным элементом» (Воривода);

б) включение в состав арго лексем из других лексических систем; например, в словаре В. Хукка «Жаргон и аббревиатура преступного мира» (название словаря явно не отражает сути, поскольку при формировании словника составитель отдал предпочтение аббревиатурам) имеются просторечные слова гавкать - «кричать; ругаться; вести неприятный разговор», грива - «волосы, прическа», литературные слова блефовать - «рисковать; запутывать партнеров при игре в карты», $n a c$ - «пропущенный ход в карточной игре» (Хукка);

в) наличие неточностей в формулировках значений; например, в «Словаре воровского и арестантского языка» пристава В.М. Попова выражение семь верст до небес и все лесом толкуется как «поговорка, означающая человека, который слова правды не скажет» (Попов, с. 43), однако в нашей картотеке она зафиксирована в значении «лгун»; в словнике П. Фабричного «Язык каторги» фразеологизм взять по делу интерпретируется как «неосто- 
рожным поведением на допросах оговорить другого и привести с собой в тюрьму» (Фабричный, с. 177), а проведенные нами исследования убеждают в том, что он имеет значение «нечаянно выдать на допросах сообщника, который в результате этого невольного предательства может оказаться в местах лишения свободы»;

г) включение в словари арго окказионализмов; так, в «Словарь тюремно-лагерно-блатного жаргона» вошло слово зарево «освещение запретной зоны ИТУ» (Балдаев, Белко, Исупов, с. 48), хотя в арго такого слова нет;

д) включение в словари таких единиц, происхождение которых неясно: то ли эти слова придуманы составителями, то ли взяты из других лексических систем, по-видимому, с целью увеличения объема словаря; например, слово жаргон - «драгоценный камень желто-красного цвета» (Мильяненков, с. 64) встречается у В.И. Даля в «Толковом словаре живого великорусского языка» почти с тем же значением (Даль, т. I, с. 74), а в современном арго оно отсутствует;

е) толкование арготизмов посредством общеупотребительных синонимов, см., например: (Быков, с. 67); однако это недопустимо, поскольку, как правило, для блатного слова нет эквивалента среди общеупотребительных лексем (Грачев, 1997, с. 65);

ж) наличие ошибок в установлении этимологии арготизмов; например, в «Толковом словаре уголовных жаргонов» происхождение лексемы пахан - «отец» связано, по мнению составителей, с устарелым общенародным слово папахен - «папочка» (Дубягин, Бронников, с. 48), тогда как пахан происходит от офенского слова похан - «хозяин»;

3) отсутствие во многих словарях ссылок на источники или на время фиксации, что способствует восприятию читателями дореволюционных арготизмов как современных; в ряде случаев дореволюционные арготизмы «подгоняются» под современные, видимо, для увеличения объема словаря в коммерческих целях; так, в «Словаре воровского языка», изданном в Тюмени (автор(ы) и редактор не указаны) обнаруживаем выражение окрестить джека - «уничтожить номер или надпись на похищенном, поставив вы- мышленное» (Словарь воровского языка, c. 24), но, как показывают наши наблюдения, в современном арго такой фразеологизм отсутствует, а в дореволюционном арго окрестить джека означало «выскоблить номер, вензель, надпись на краденых часах и выставить вымышленное»;

и) отсутствие в большинстве словарей ударений, грамматической характеристики, контекста, нарушение алфавитного порядка расположения заглавных слов;

к) отсутствие ссылок на источник при заимствовании информации, в том числе и из других словарей; например, В. Попов ввел в свой «Словарь воровского и арестантского языка» арготизмы и их толкования, используя роман Вс. Крестовского «Петербургские трущобы» (Крестовский) и словарь В. Трахтенберга «Блатная музыка. Жаргон тюрьмы» (Трахтенберг) без отсылок к тексту первоисточника.

Таким образом, все имеющиеся словари русского арго не свободны от существенных недостатков. Между тем на эти словари ссылаются как на образцовые, тиражируя допущенные в них ошибки и неточности (что, безусловно, вредит науке о языке), даже крупные ученые-лингвисты, составители фундаментальных словарей, соискатели, работающие над кандидатскими и докторскими диссертациями.

С учетом высказанных критических замечаний, нашего лексикографического опыта (Грачев, 1991; 1992; 1996; 1997; 2003; Грачев, Гуров; Грачев, Мокиенко) и разработанных теоретических подходов (см. Грачев, 1997) считаем необходимым издание нового словаря русского арго.

\section{Принципы составления нового словаря русского арго}

Словник в словаре должен охватывать арготическую лексику, начиная со слов, зафиксированных в фольклоре, и заканчивая современными арготизмами.

При составлении данного словаря автоp(ы) обязательно столкне(у)тся с четырьмя основными трудностями:

- отсутствие в науке четких критериев отнесения слова к арго; 
- отсутствие у арготизмов, фиксируемых в ряде ранних источников, ударения, грамматической характеристики и контекста;

- ненадежность источников арготизмов;

- отсутствие в ранних письменных источниках (например, в летописях, былинах, разбойничьих песнях) указаний на слово как на арготизм.

Следовательно, необходимо выработать методику квалификации слова как арго. Предлагается учитывать следующее:

1) наличие в семантике слова указания на явно арготическую сферу употребления (например, арготизм птичка имеет значение «инструмент, предназначенный для взлома сейфов»);

2) частотность словоупотребления;

3) признание слова носителями арго как «своей» лексемы (этот критерий применим только к современным лексемам); фиксация слова в словарях арго;

4) указание в толковых словарях русского языка на использование этого слова в среде деклассированных элементов;

5) признание его арготизмом в лингвистических научных работах, посвященных лексике деклассированных элементов;

6) неизвестность слова другим социальным группам населения;

7) использование слова как арготизма в художественных текстах с указанием на это автором произведения;

$8)$ особенности словообразования и использование специфических аффиксов в структуре арготизмов;

9) печать ненормативности;

10) наличие ярко выраженной эмоционально-экспрессивной окраски.

Ряд слов образует диффузную зону (так называемый бижаргон и интержаргон). В этот смешанный пласт лексики попадают общеупотребительные бытовые слова и некоторые профессиональные лексемы из социальных диалектов. В отдельных случаях трудно определить направление заимствования таких слов. Например, лексемы висяк, глухарь - «нераскрытое преступление», смарафетить «искусственно создать улики преступления» являются общими для речи представителей правоохранительных органов и деклассированных элементов; валя - «валюта», лимон - «миллион рублей», нал - «наличные деньги; расчет наличными деньгами» относятся к интержаргонным для деклассированных элементов и предпринимателей.

При составлении словаря следует учесть хронологическую отнесенность лексем: в одном временном отрезке слова являлись арготизмами, в другом - функционировали в иной лексической системе. Например, слово липа «поддельный документ» в XIX - нач. XX в. было арготизмом, а в середине XX в. - просторечным словом; лексема двурушник, обозначавшая в речи нищих в XIX в. попрошайку, протягивающего две руки за подаянием, в $\mathrm{XX}$ в. перешла в разговорно-литературный язык и стала называть человека, который под личиной преданности кому-чему-н. действует в пользу враждебной стороны.

Кроме того, нужно принимать во внимание изменчивость наказаний за те или иные преступления, отражающуюся в арго. Например, в 30-80-е гг. XX в. перепродажа предметов по более высокой цене расценивалась как уголовно наказуемое деяние - спекулянтство (ст. 121 УК РСФСР), поэтому язык спекулянтов того периода необходимо относить к арго.

До сих пор не описана методика сбора «живого» материала криминальных элементов [Грачев, Кожевников, 1996, с. 18]. Нам представляется нецелесообразным сбор материала «в открытую»: при помощи видных для информанта диктофона, магнитофона, мобильного телефона, записных книжек и блокнотов. В этом случае собеседник замыкается. Дело не только в том, что данные технические средства ассоциируются у него с допросом - нередко информант не хочет раскрывать своих тайн, так как любого «непреступника» профессиональный уголовник считает социальным врагом или, по меньшей мере, человеком низшего ранга; см. арготические пренебрежительные названия собирателя блатных слов: полукровка, феня в ботах, ивветной.

Современный арготический материал можно получать в результате непосредственного наблюдения за «живой» речью криминальных элементов, выборки арготизмов из тюремного фольклора: блатных песен, поговорок, пословиц, афоризмов. При сборе лексического материала в процессе непосред- 
М.А. Грачев. Лексикографические проблемы составления словарей арго

ственного общения с представителями криминального мира можно использовать «принцип запоминания» и последующее воссоздание и фиксацию разговоров, бесед, скрытые мобильный телефон или диктофон, а также приобрести (купить) у лиц, побывавших в местах лишения свободы, записные книжки, альбомы, в которых зафиксированы элементы субкультуры преступного мира, и извлечь из них арготизмы [Грачев, 2009, с. 128].

Для сравнения и крайне осторожно, принимая во внимание все сказанное выше, следует использовать и современные словари арго.

Арготизмы более раннего периода необходимо собирать из разных источников: летописей, рукописей некоторых исследователей арго [Лихачев, 1935], научных статей и монографий, документальной и художественной литературы, словарей арго и толковых словарей русского языка. При этом важно учитывать, что в ранних словарях и исследованиях, посвященных арго, встречались неточности при отнесении слова к арго. Эти факты нужно подвергать тщательной проверке. Опыт такой работы показывает, что, к сожалению, большинство собирателей арго в XIX - нач. XX в. фиксировали слова без ударения, грамматической характеристики и контекста, поэтому у значительной части дореволюционных арготизмов данные атрибуты могут отсутствовать [Кучинский, 1998].

\section{Структура нового словаря русского арго}

Состав словарной статьи. В связи со сложностью словарного состава, статьи в словаре располагаются в алфавитном порядке по заглавному слову. Однако в зависимости от фонетической, графической и морфологической близости в статью могут входить другие слова.

При заглавном слове, в качестве которого выступает существительное, даются варианты, например: бан - бон, клиф - клифт клифта, фрайер - фраер.

В ряде случаев, когда имеются основания полагать, что это разные по происхождению лексемы, слова даются отдельными статьями, например:
НАЛЯБЗИТЬ -зю, -зишь; сов. Наворовать.

НАЛЯМЗИТЬ -зю, -зишь; сов. То же, что НАЛЯБЗИТЬ.

В словарной статье, где заглавным словом является глагол, указываются формы совершенного и несовершенного вида, образованные посредством суффиксов, а также причастия и деепричастия (арготизмы, извлеченные из письменных источников), например:

ДУТЬ -ю, -ешь; несов. Доносить на кого-л. ДУНУТЬ -ну, -нешь; сов.

ССУЧИТЬСЯ -чусь, -чишься; сов. Стать СУКОЙ. ССУЧИВШИЙСЯ -аяся, -ееся.

ПОВЯЗАТЬ -жу, -жешь; сов. Арестовать. ПОВЯЗАННЫЙ -ая, -ое. ПОВЯЗАВ.

Кроме того, в словарной статье могут находиться варианты глаголов и глагольных форм, а также фразеологизмов:

ОТКИНУТЬ ХВОСТ - умереть. Лабутя уже давно хвост откинул. ОТКИНУТЬ ХВОСТА. Бабке скажи, чтобы быстрее хвоста бросала.

В одной словарной статье должны находиться фразеологизмы с глаголом совершенного и несовершенного вида в качестве главного слова, например:

ТИСКАТЬ РОМАН - рассказывать интересные истории. ТИСНУТЬ РОМАН.

Ссылочные слова. В общем алфавитном порядке в словарь необходимо ввести ссылочные слова:

- если они тождественны по значению и находятся в непосредственной близости друг от друга (в арго большое количество абсолютных синонимов), например:

ЗАСЫПАТЬСЯ -люсь, -лешься; сов. Попасться при совершении преступления.

ЗАШИТЬСЯ -юсь, -ешься; сов. То же, что ЗАСЫПАТЬСЯ.

ЗАШУХЕРОВАТЬСЯ -юсь, -ешься; сов. То же, что ЗАСЫПАТЬСЯ;

- при формах глагола совершенного и несовершенного вида, если они образованы посредством префиксов, например:

ВЯЗАТЬ -жу, -жешь; несов. Прекращать. ЗАВЯЗАТЬ -жу, -жешь; сов. См. ВЯЗАТЬ. 
ДОШИРЯТЬСЯ -юсь, -ешься; сов. См. ШИРЯТЬСЯ.

ШИРЯТЬСЯ -юсь, -ешься; несов. Вводить в организм наркотики шприцем;

- если в качестве заглавного слова приводится не главное слово фразеологизма, а грамматически ему подчиненное (ссылка дается на главное слово, входящее во фразеологический оборот), например:

ГНУТЬ НА ПОДЛЯНКУ - агитировать на подлое дело.

ПОДЛЯНКУ. ГНУТЬ НА ПОДЛЯНКУ см. ГНУТЬ

ДАВАТЬ ДЕЛО - заводить дело на преступника. ДЕЛО. ДАВАТЬ ДЕЛО - см. ДАВАТЬ;

- если рядом с устойчивым словосочетанием стоит одинаковый по лексическому значению фразеологизм (ссылка дается на предыдущий фразеологизм), например:

ЗАПУСКАТЬ АРАПА - обманывать.

ЗАРЯЖАТЬ ТУФТУ - то же, что ЗАПУСКАТЬ АРАПА.

Толкование значения слова. Лексические значения в многозначных словах разделяются арабскими цифрами, например:

КСИВА-ы, ж. 1. Документ. 2. Письмо. 3. Записка. ЛЕГАВЫЙ -ого, м. 1. Сотрудник правоохранительных органов. 2. Предатель.

ПАХАН -а, м. 1. Отец. 2. Старик.

Случаи сомнительного толкования (как правило, это касается лексем ранней фиксации), должны сопровождаться вопросительным знаком, например:

НАКОЛОТЬ ХАЗОВКУ - высмотреть квартиру (как объект кражи?).

Омонимы даются как заглавные слова в разных статьях, например:

АКАДЕМИЯ 1 -ии, ж. Сбор шулеров для решения организационных вопросов и обмена опытом.

АКАДЕМИЯ ${ }^{2}$-ии, ж. Тюрьма.

ВЗять ${ }^{1}$-му, -мешь; сов. Арестовать.

ВЗЯТь $^{2}$-му, -мешь; сов. Ограбить.

ПАРАША ${ }^{1}$-и, ж. Емкость для нечистот и испражнений в местах лишения свободы.

ПАРАША ${ }^{2}$-и, ж. Ложный слух; сплетня.
Контекст. После толкования слова приводятся примеры, которые иллюстрируют его функционирование. Они должны быть взяты из «живой» речи (для современных арготизмов) или из письменных источников - летописей, былин, художественных и научных произведений (для арготизмов ранней фиксации) с указанием на источник. Контекст может состоять из одного или нескольких предложений (в зависимости от употребительности арготизма). Поскольку в словаре дается лишь иллюстрация употребления арготизма, контексты приводятся из одного или нескольких произведений, а не все случаи использования блатной лексемы в художественных произведениях. Многочисленность примеров указывает на активность данной лексемы. Иногда для доказательства того, что арготизм не является окказионализмом, можно привести несколько примеров из одного и того же произведения. При одном слове может быть контекст как из художественной литературы, так и из «живой» речи. «Живой» контекст должен быть адаптирован, например, из него исключаются нецензурные слова, но сохраняется смысл. Контекст должен приводиться к каждому варианту и форме слова, а также фразеологизму. См. примеры:

КОРЕШ -a, м. Товарищ, друг. Чтобы я блатного кореша и уголовке сдал - да ни в жисть (А. и Г. Вайнеры. Эра Милосердия).

ШМОН -а, м. Обыск. Шмон мы проведем бесшумно да аккуратно, потому ничего нам не надо, кроме Тамарки. (В. Высоцкий. Поэзия и проза). Носилки поставили прямо на землю. Ждем шмона. (А. Марченко. Мои показания).

Для ранних арготизмов характерен дефицит контекста, так как собиратели и составители словарей (словников) в большинстве случаев не считали нужным включать его в словарную статью. Поэтому в новом словаре для некоторых ранних арготизмов в качестве контекста можно использовать одни и те же предложения (но для разных слов) из художественной, публицистической и научной литературы:

C ВЕТРУ - пришедший неведомо откуда и занимающийся воровством в одиночку (Поп., Пот.);

- Рожа-то его что-то мне незнакома, - пробурчал Летучий, подойдя к Вересову и вглядыва- 
М.А. Грачев. Лексикографические проблемы составления словарей арго

ясь в лицо. - Ребятки! - обернулся он к толпе, - не признает ли кто молодца? Хороводный он откольнибудь, аль с ветру?

- Не надо быть, чтобы хороводный! Кабы хороводныци, мы бы знали, кто-нибудь да узнал бы беспременно, - отозвались из толпы несколько записных жоржей. Летучий.

- Так, стало быть, с ветру? - снова обернулся

- С ветру!.. На особняка, значит, ходит, - подтвердили жоржи. (Вс. Крестовский. Петербургские трущобы).

ХОДИТЬ НА ОСОБНЯК - совершать преступления в одиночку (Поп., Пот.).

- Рожа-то его что-то мне незнакома, - пробурчал Летучий, подойдя к Вересову и вглядываясь в лицо. - Ребятки! - обернулся он к толпе, не признает ли кто молодца? Хороводный он отколь-нибудь, аль с ветру?

- Не надо быть, чтобы хороводный! Кабы хороводныци, мы бы знали, кто-нибудь да узнал бы беспременно, - отозвались из толпы несколько записных жоржей. Летучий.

- Так, стало быть, с ветру? - снова обернулся

- С ветру!.. На особняка, значит, ходит, - подтвердили жоржи. (Вс. Крестовский. Петербургские трущобы).

Фразеологизмы. Эти лексические единицы с толкованием приводятся после знака • , например:

- ВЫБИТЬБУБНУ - избить.

- ЧУВЫРЛО БРАТСКОЕ - отвратительная физиономия.

- БЫТЬ НА СТРЕМЕ - стоять на страже во время совершения преступления и, в случае тревоги, подавать сигналы своим товарищам.

Ударение в словаре обозначается специальным знаком (') сверху над гласной. Поскольку арготизмы - это слова, образованные в основном от просторечной, диалектной и литературной лексики, то чаще всего ударение в них не отличается от ударения в словах этих подсистем русского языка. Довольно редко встречается изменение позиции ударения, например, РО́МАН. В то же время в ранних арготизмах ударение не проставлено, потому что в настоящее время неизвестно, как произносилось то или иное слово.

Во фразеологических оборотах знак ударения, за редким исключением, ставится на знаменательных словах, например:
ВЕРТЕ́ТЬ ВОЛА́- обманывать.

Если имеются сомнения в произношении того или иного арготизма, то рядом можно указать возможный фонетический вариант этого слова с вопросительным знаком, например:

Ши́ ТВИС (ШИТВИ́С?) - шайка преступников.

О́TOРВА (ОТОРВÁ) -ы, ж. 1. Проститутка. 2. Любовница вора. 3. Профессиональная преступница, которая отбирает узаключенных вещи и продукты питания.

В некоторых арготизмах, прежде всего дореволюционных, ударение отсутствует.

Грамматическая характеристика слов. Существенных грамматических особенностей в арго не наблюдается. Арготизмам раннего периода можно дать современные грамматические характеристики, хотя их следует считать возможными, вариативными.

К каждому заглавному слову (словам) нужно дать помету, которая бы указывала на его (их) принадлежность к той или иной части речи. Так, при наречии, междометии, слове категории состояния должны приводиться следующие пометы: нареч., межд., сл. катег. сост. Принадлежность слова к существительному маркируется окончанием род. п. ед. ч. и указанием на род; к глаголу - окончанием 1-го и 2-го л. ед. ч. наст. вр. и указанием на вид; прилагательного - окончанием мужского, женского и среднего рода ед. ч. им. п.

Имя существительное. Существительные в словаре даются в форме им. п. ед. ч., затем указывается окончание род. п. ед. ч и род (пометы: м. - мужской, ж. - женский, ср. - средний), например:

$$
\begin{aligned}
& \text { НЕДОБЫЧНИК -a, м. } \\
& \text { ИГРУШКА -и, ж. } \\
& \text { ФАРМАЗОНСТВО -a, cp. }
\end{aligned}
$$

При несклоняемых существительных дается помета «нескл.», например:

МЕТРО нескл., ср.

ЧМО нескл., ср.

В тех случаях, когда существительное имеет только множественное число, используется помета «мн. ч.», например: 
МАРКОТАШКИ -Ø, мН.ч.

СТИРЫ -Ø, мн. ч.

Иногда имеются расхождения между арготизмом и тем литературным словом, от которого он образован.

Двойные пометы рода - «м. и ж.» указывают на возможное употребление существительного и в мужском, и в женском роде, например:

МОРФУША -и, м. и ж.

Помета «собир.» означает, что существительное является собирательным, например:

БЛАТНЯ -и, ж., собир.

ШПАНА -ы, ж., собир.

Следует заметить, что некоторые существительные литературного языка в арго переходят в другой разряд. Например, мусор как общеупотребительное слово относится к вещественным существительным, а в арго к конкретным, поскольку имеет значение «сотрудник милиции», см. пример из блатной песни «Задумал, братцы, пошухерить»: Перемахнул я с полста дворов / И сбил со следа всех мусоров...

Имя прилагательное приводится в им. п. мужского рода в полной форме, далее указываются окончания женского и среднего рода, например:

ВЕРТУХАЕВСКИЙ -ая, -ое. ФРАЕРСКОЙ -ая, -ое.

Глагол в словаре дается в форме инфинитива. После него приводятся окончания 1-го и 2-го л. ед. ч. наст. вр., сокращения «сов.» (совершенный вид) и «несов.» (несовершенный вид), например:

ЗАСВЕЧИВАТЬ -ваю, -ваешь; несов.

ПРОМОКНУТЬ -ну, -нешь; сов.

У безличных глаголов указывается окончание 3-го л. ед. ч. наст вр. и дается помета «безл.» (безличный), например:

СВЕТИТЬ -ит; безл.; несов.

ФАРТИТЬ -ит; безл.; несов.
Если есть сомнения в способности слова иметь определенную грамматическую форму, то после предполагаемой грамматической формы ставится вопросительный знак, например:

ЗЭТИТЬ -чу?, -тю?, -тишь; несов.

Чтобы читателю было понятно, как произносится глагол в форме 1-го и 2-го л. наст. вр. окончание приводится с предшествующими звуками основы.

Этимология. Арготические слова имеют сложную этимологию. Многие из них образованы на русской почве, другие заимствованы из иностранных языков. Краткие этимологические сведения приводятся в круглых скобках после контекста.

\section{Причины и направления развития арго}

При составлении словаря арго (а он должен пополняться через каждые пять-семь лет) важно прогнозировать процессы, происходящие в криминальном мире. Известно, что язык отражает происходящее в обществе. Арго уродливый «ребенок» русского языка - отражает те явления, которые происходят, прежде всего, в маргинальных сферах российского социума.

В настоящее время наблюдается трансформация криминального мира. Увеличилось количество вымогателей - резко расширился и состав их арго: коммерсила, барыга«коммерсант, предприниматель», лоховская кормушка - «фирма, которая платит дань вымогателям», кабанчик - «предприниматель, тесно связанный с профессиональными преступниками», бомбить - «заниматься рэкетом коммерсантов». Возродилась старая профессия воров-медвежатников, а с ними и блатные слова: шаер - «ломик, предназначенный для взлома», видра - «отмычка», шмель - «сверло, предназначенное для вскрытия сейфов».

У современных преступников более тесными стали связи с заграницей, а значит, можно ожидать пополнения лексикона арго большим количеством западноевропеизмов, американизмов, а также слов из Азии, в частности из китайского языка. 
Появились новые виды преступлений: из самых опасных можно назвать хакерство, незаконную трансплантацию человеческих органов, терроризм, радикальное религиозное сектантства, работорговлю. Следовательно, в ближайшее время сформируются новые специализированные арго. Либерализм законов и развитие капиталистических отношений способствуют росту численности криминальных элементов. В частности, в последнее время увеличивается количество лиц без определенного места жительства, которые тоже используют в речи арготизмы.

На динамику арго в России оказывает влияние формирование новой профессиональной преступности: делятся сферы влияния между уголовными группировками, определяется место в криминальном мире воров в законе и бандитов и т. п.

Организованные преступные группировки (ОПГ) имеют доступ к достижениям технического прогресса: все, что представляет материальную ценность, должно иметь название и в арго. Например, в арго воров-карманников пятнадцать лет назад появилось специальное слово - дебильник - «мобильный сотовый телефон». Использование современной техники (например, приборов ночного видения) и оружия, связь с хакерами, про-геймерами все это нашло или должно найти отражение в арго криминального мира. Язык уголовников пока не успевает за всеми веяниями в обществе (или исследователи арго не успевают следить за всеми новшествами, которые появляются в нем?).

В последнее время наблюдается изменение связей элиты преступного мира с правоохранительными органами, государственной и муниципальной администрацией, которое приводит к резкому пополнению бижаргона сотрудников правоохранительных органов и преступников. Связь традиционных уголовников и военных обнаруживается во влиянии военного жаргона на арго и наоборот.

Отмеченные нами изменения в языке криминального мира позволяют предложить деление арго на традиционное, связанное с традиционными преступлениями, например, воровством, которое совершают воры-карманники, домушники и проч.), и нетрадиционное, связанное с жаргонами правоохранителей и современных технических работников, прежде всего специалистов по IT-технологиям.

\section{Заключение}

Трансформации в жизни российского общества, проявившиеся в усилении криминального мира, его влияние на власть, литературу, эстраду, язык создают в социуме (в значительной его части) благоприятную психологическую почву для восприятия блатных слов. Существенную роль в том, что арготизмы не воспринимаются населением России как нечто экзотичное или запретное, засоряющее русский язык, играют СМИ и Интернет (например, на первом канале центрального государственного телевидения идет передача «Три аккорда», в которой исполняются песни, содержащие в большом количестве арготические лексемы). Кроме того, арготизмы, обладая экспрессивностью и яркой отрицательной окраской, активно переходят в общенародный язык. Лингвисты не могут повлиять на этот процесс: журналисты к ним не прислушиваются, во многих газетах, на радио и телевидении редакторская правка отсутствует; закон, регулирующий публичное речевое поведение, не разрабатывается и не обсуждается.

Чтобы замедлить процесс влияния арготизмов и - шире - всей тюремной субкультуры на законопослушное общество, нужно как можно быстрее принять радикальные меры. Думается, что появление нового качественного, квалифицированно составленного словаря русского арго будет одной из мер, нацеленных на изменение отношения социума к языку криминального мира.

\section{СПИСОК ЛИТЕРАТУРЫ}

Грачев М. А., 2009. Лингвокриминалистика. Нижний Новгород : НГЛУ им. Н.А. Добролюбова. $280 \mathrm{c.}$

Грачев М. А., Кожевников А. Ю., 1996. К вопросу о социальной диалектологии русского языка // Филологические науки. № 5. С. 18-25.

Грачев М. А., Сапожникова О. С., 2004. Некоторые теоретические подходы к составлению двуязычного словаря социолектизмов // Социальные варианты языка-ІІІ : материалы междунар. науч. конф. (22-23 апреля 2004 г.). Ниж- 
ний Новгород : Нижегор. гос. лингвист. ун-т им. Н.А. Добролюбова. С. 37-40.

Кучинский А. В., 1998. Преступники и преступления. Законы преступного мира. Обычаи, язык, татуировки: Энциклопедия. Донецк : Сталкер. $486 \mathrm{c}$.

Лихачев Д. С., 1935. Черты первобытного примитивизма воровской речи // Язык и мышление. M. ; Л. : Изд-во Академии наук CCCP. T. III-IV. C. 47-100.

\section{ИСТОЧНИКИ И СЛОВАРИ}

Балдаев, Белко, Исупов - Словарь тюремно-лагерно-блатного жаргона (речевой и графический портрет советской тюрьмы) / авт.-сост. Д. С. Балдаев, В. К. Белко, И. М. Исупов. М. : Края Москвы, 1992. 526 с.

Быков - Быков В. Русская феня: Словарь современного интержаргона асоциальных элементов. Смоленск : ТРАСТ-ИМАКОМ, 1993. 222 с.

Вийон - Вийон Ф. Я знаю все, но только не себя. Баллады / пер. с фр., сост. и авт. коммент. Е. Витковский. М. : ЭКСМО-ПРЕСС, 1999. 448 с.

Воривода-Воривода И. Сборник жаргонных слов и выражений, употребляемых в устной и письменной речи преступным элементом. АлмаАта : МВД КазССР, 1971. 106 с.

Грачев, 1991 - Грачев М. А. Словарь дореволюционного арго. Нижний Новгород : Жеко, $1991.168 \mathrm{c}$

Грачев, 1992 - Грачев М. А. Язык из мрака - блатная музыка и феня: Словарь. Нижний Новгород : Флокс, 1992. 202 с.

Грачев, 1996 - Грачев М. А. Жаргон и татуировки наркоманов: Краткий словарь-справочник. Нижний Новгород : Нижегор. гуманитар. центр, 1996. $75 \mathrm{c}$.

Грачев, 1997 - Грачев М. А. Русское арго. Нижний Новгород : Изд-во НГУ, 1997. 286 с.

Грачев, 2003 - Грачев М. А. Словарь тысячелетнего русского арго. М. : РИПОЛ-Классик, 2003. $1320 \mathrm{c}$.

Грачев, Гуров - Грачев М. А., Гуров А. И. Словарь молодежных сленгов. Горький : Обком ВЛКСМ, $1989.78 \mathrm{c}$.

Грачев, Мокиенко - Грачев М. А., Мокиенко В. М. Историко-этимологический словарь воровского жаргона. СПб. : Фолио-Пресс, 2000. 256 с.

Гюго - Гюго В. Отверженные / пер. с фр. А. Виноградова. М. : БММ : Литература ; Харьков : Книжный Клуб «Клуб Семейного Досуга», $2013.630 \mathrm{c}$

Даль - Даль В. И. Толковый словарь живого великорусского языка : в 4 т. М. : ТЕРРА, 1994.
Дубягин, Бронников - Толковый словарь уголовных жаргонов / под общ. ред. Ю. П. Дубягина, А. Г. Бронникова. М. : Интер-ОМНИС : POMOC, $1991.288 \mathrm{c}$.

Крестовский - Крестовский В. В. Петербургские трущобы: Книга о сытых и голодных. М. : Пресca, 1994. $634 \mathrm{c}$.

Мильяненков - Мильяненков Л. А. По ту сторону закона: Энциклопедия преступного мира. СПб. : Дамы и господа, 1992. 320 с.

Никоноров - Никоноров М. Г. Сборник жаргонных слов и выражений, употребляемых в устной и письменной форме преступным элементом. М. : ГУИТУ, 1978. $126 \mathrm{c.}$

Попов - Попов В. М. Словарь воровского и арестантского языка. Киев : Печатня, 1912. 112 с.

Словарь воровского языка - Словарь воровского языка: Слова. Выражения. Жесты. Татуировки. Тюмень : НИЛПО, 1991. 172 с.

Трахтенберг - Трахтенберг В. Ф. Блатная музыка: Жаргон тюрьмы / под ред. и с предисл. И. А. Бодуэна де Куртенэ. СПб. : тип. А.Г. Розена, 1908. $116 \mathrm{c}$.

Фабричный - Фабричный П. Язык каторги // Каторга и ссылка. 1923. № 6. С. 177-178.

Хукка - Хукка В. С. Жаргон и аббревиатура татуировок преступного мира : словарь-справочник. Нижний Новгород : Нижполиграф, 1992. 233 с.

\section{REFERENCES}

Grachev M.A., 2009. Lingvocriminalistics. Nizhny Novgorod, Linguistics University of Nizhny Novgorod named after N.A. Dobrolyubov Publ. $280 \mathrm{p}$.

Grachev M.A., Kozhevnikov A.Yu., 1996. On the Issue of Social Dialectology of the Russian Language. Filologicheskie nauki [Philological Sciences], no. 5, pp. 18-25.

Grachev M.A., Sapozhnikova O.S., 2004. Some Theoretical Approaches to Compilating the Bilingual Dictionary of Sociolects. Sotsialnye varianty yazyka-III : Materialy mezhdunarodnoy nauchnoy konferentsii (22-23 aprelya 2004 goda) [Social Variants of the Language-3: Proceedings of the International Conference (2223 April 2004)]. Nizhny Novgorod, Linguistics University of Nizhny Novgorod named after N.A. Dobrolyubov Publ., pp. 37-40.

Kuchinskiy A.V., 1998. Perpetrators and Crimes. The Laws of the Criminal World. Customs, Language, Tattoos: Encyclopedia. Donetsk, Stalker Publ. 486 p.

Likhachev D.S., 1935. The Primitivistic Features of Criminal Speech. Yazyk i myshlenie [Language 
and thinking]. Moscow: Leningrad, Akademiya nauk SSSR Publ. Vols. 3-4, pp. 47-100.

\section{SOURCES AND DICTIONARIES}

Baldaev D.S., Belko V.K., Isupov I.M. Criminal Slang Dictionary: Speech and Grafic Portrait of a Soviet Prison. Moscow, Kraya Moskvy Publ., 1992. $526 \mathrm{p}$.

Bykov V. Russian Fenya: the Dictionary of Modern Interjargon of Anti-social Elements. Smolensk, TRAST-IMAKOM Publ., 1993. 222 p.

Villon F. I Know Everything but myself. Ballads. Moscow, EKSMO-PRESS Publ., 1999. 448 p.

Vorivoda I. Collection of Jargon Words and Expressions Used in Oral and Written Speech by the Criminal Element. Alma-Ata, MVD KazSSR, 1971. 106p.

Grachev M.A., 1991. Dictionary of Pre-revolutionary Argot. Nizhny Novgorod, Zheko Publ., 1991. $168 \mathrm{p}$.

Grachev M.A., 1992. The Language of Darkness Criminal Music and Fenya: Dictionary. Nizhny Novgorod, Phlox Publ., 1992. 202 p.

Grachev M.A., 1996. Jargon and Tattoos of Addicts: a Brief Dictionary. Nizhny Novgorod, Nizhegorodskiy gumanitarnyy tsentr Publ., 1996. $75 \mathrm{p}$.

Grachev M.A., 1997. Russian Argo. Nizhny Novgorod, NGU Publ., 1997. 286 p.

Grachev M.A., 2003. Dictionary of the Thousandyear Russian Slang. Moscow, RIPOL-Klassik Publ., 2003. 1320 p.

Grachev M.A., Gurov A.I. The Dictionary of Youth Slangs. Gorky, Obkom VLKSM Publ., 1989. 78 p.
Grachev M.A., Mokienko V.M. Historical and Etymological Dictionary of Thieves' Jargon. Saint-Petersburg, Folio-Press Publ., 2000. 256 p.

Hugo V. Les Miserables. Translation from French. Moscow, BMM Publ., Literatura Publ.; Kharkiv, Knizhnyy Klub "Klub Semeynogo Dosuga" Publ., 2013.630 p.

Dal V.I. The Explanatory Dictionary of the Living Great Russian Language. In 4 vols. Moscow, TERRA Publ., 1994.

Dubyagin Yu.P., Bronnikov A.G., eds. Explanatory Dictionary of Criminal Jargons . Moscow, InterOMNIS; ROMOS Publ., 1991. 288 p.

Krestovskiy V.V. St. Petersburg Slums. The Book about Full and Hungry. Novel in six Parts. Moscow, Pressa Publ., 1994. 634 p.

Milyanenkov L.A. On the Wrong Side of the Law. Encyclopedia of the Underworld. Saint Petersburg, Damy i gospoda Publ., 1992. 320 p.

Nikonorov M.G. Collection of Jargon Words and Expressions Used Orally and in Writing by the Criminal Element. Moscow, GUITU Publ., 1978. $126 \mathrm{p}$.

Popov V.M. Dictionary of Thieves 'and Prisoners' Language. Kiev, Pechatnya Publ., 1912. 112 p.

Dictionary of Thieves' Language: Words. Expressions. Gestures. Tattoos. Tyumen, NILPO Publ., 1991. $172 \mathrm{p}$.

Trachtenberg V.F. Thug Music: the Jargon of the Prison. Saint Petersburg, Tipografiya A.G. Rosena, 1908. $116 \mathrm{p}$.

Fabrichnyy P. The Language of Penal Servitude. Penal Servitude and Exile, 1923, no. 6, pp. 177-178.

Hukka V.S. Jargon and Abbreviation of Tattoos of the Underworld: Dictionary-and Digest. Nizhny Novgorod, NizhpoligrafPubl., 1992. 233 p.

\section{Information about the Author}

Mikhail A. Grachev, Doctor of Sciences (Philology), Professor, Department of Russian Philology, Foreign Literature and Cross-Cultural communication, Nizhniy Novgorod State Linguistic University after N.A. Dobrolubov, Minin St., 31A, 603005 Nizhniy Novgorod, Russia, ma-grachev@mail.ru, https://orcid.org/ 0000-0001-7972-4033

\section{Информация об авторе}

Михаил Александрович Грачев, доктор филологических наук, профессор кафедры русской филологии, зарубежной литературы и межкультурной коммуникации, Нижегородский государственный лингвистический университет им. Н.А. Добролюбова, ул. Минина, 31А, 603005 г. Нижний Новгород, Россия, ma-grachev@mail.ru, https://orcid.org/0000-0001-7972-4033 